\title{
SOSIALISASI MENUJU PENERAPAN ADAPTASI KEBIASAAN BARU PADA SANTRI PONDOK PESANTREN DI KABUPATEN LUMAJANG
}

\section{THE SOCIALIZATION TOWARDS IMPLEMENTATION NEW HABITS ADAPTATION FOR STUDENT OF ISLAMIC BOARDING SCHOOL IN LUMAJANG}

\author{
Dita Fahrun Nisa ${ }^{1}$ \\ ${ }^{1}$ Departemen Administrasi dan Kebijakan Kesehatan, Fakultas Kesehatan Masyarakat \\ Universitas Airlangga \\ email : dita.fahrun.nisa-2016@fkm.unair.ac.id
}

\begin{abstract}
The Coronavirus Disease 2019 ( COVID-19) pandemic has become a global health problem and has occurred in more than 200 countries around the world, including Indonesia. Every effort has been made to prevent the transmission of COVID-19. First, the Indonesian government appela stay at home policy and even a regional quarantine, but then the new habit was adapted. This adaptation is a period where all sectors begin to return to normal but still pay attention to implement the health protocols. This policy is carried out in all provinces in Indonesia, including East Java. In East Java, all Islamic boarding schools have been allowed to return to their respective cottages after previously being discharged to prevent transmission of COVID-19. Likewise in Lumajang Regency, even though it is a red zone, all Islamic boarding schools have started to accept the students of boarding schools known as "santri" usually live in them back during the for new habits adaptation. The method used is socialization and prcatical of hadwahsing using standard according to WHO. This activity was attended by 60 students who were accompanied by teachers and administrators of Islamic boarding schools. The pre-test and post-test activities were carried out to assess the knowledge held. As a result, there is an increase in the knowledge of students regarding the material provided, namely the prevention of COVID-19 and health protocols that must be carried out.
\end{abstract}

Keyword: COVID-19, Pandemic, Socialization

\section{abstrak}

Pandemi Coronavirus Disease 2019 (COVID-19) telah menjadi masalah kesehatan global dan telah terjadi di lebih dari 200 negara dunia, termasuk Indonesia. Segala upaya telah dilakukan untuk mencegah penularan COVID-19. Pada mulanya pemerintah Indonesia memberlakukan adanya kebijakan stay at home bahkan karantina wilayah, namun kemudian dilakukan adaptasi kebiasaan baru (AKB). Adaptasi ini merupakan masa dimana seluruh sektor mulai kembali seperti normal namun tetap memperhatikan protokol kesehatan. Kebijakan ini dilakukan di seluruh provinsi yang ada di Indonesia, termasuk Jawa Timur. Di Jawa Timur, seluruh pondok pesantren sudah boleh kembali ke pondok masing-masing setelah sebelumnya dipulangkan untuk mencegah penularan COVID-19. Begitupun di Kabupaten Lumajang, meskipun merupakan zona merah tapi seluruh pondok pesantren sudah mulai menerima kembali pelajar yang melakukan aktivitas mondok yang disebut "santri" pada masa adaptasi kebiasaan baru. Metode pengabdian yang dilakukan yaitu sosialisasi dan pelaksanaan praktik cuci tangan sesuai standar WHO. Kegiatan ini diikuti oleh 60 santri yang didampingi oleh guru dan pengurus pondok pesantren. Dilakukan kegiatan pre-test dan post-test untuk menilai pengetahuan yang dimiliki. Hasilnya, terdapat peningkatan pengetahuan santri terkait materi yang diberikan yaitu pencegahan COVID-19 serta protokol kesehatan yang harus dilakukan.

Kata Kunci: COVID-19, Pandemi, Sosialisasi

\section{PENDAHULUAN}

Corona Virus Disease (COVID-19) merupakan penyakit yang disebabkan oleh SARSCoV-2. Virus ini pertama kali ditemukan di Kota Wuhan, Provinsi Hubei, China pada 31 Desember 2019. Kondisi ini telah ditetakan sebagai masalah kesehatan global oleh World Health Organization (WHO). Data terbaru hingga 07 Agustus 2020, virus ini 
telah menjangkit lebih dari 200 negara di dunia, termasuk Indonesia (WHO 2020). Virus ini pertama kali terdeteksi masuk ke Indonesia pada 2 Maret 2020 setelah terdapat dua WNI positif COVID-19. Tepat lima bulan setelah kasus pertama, yaitu pada 2 Agustus 2020 telah terdapat 121.226 orang terkonfirmasi positif. Sebanyak 77.557 diantaranya telah dinyatakan sembuh dan 5.593 dinyatakan meninggal dunia (Kemenkes 2020). Kondisi yang terjadi di Indonesia makin parah karena penyebaran virus ini telah menyebar di 34 provinsi yang ada. Salah satu provinsi dengan jumlah orang positif COVID-19 terbanyak di Indonesia adalah Jawa Timur.

Eskalasi kasus terus terjadi setiap harinya di Jawa Timur dan telah menjadi pusat perhatian yang serius oleh seluruh pihak terkait, termasuk Pemerintah Jawa Timur. Banyak kebijakan yang telah dilakukan untuk mengurangi penularan COVID-19 antara lain kebijakan stay at home, study at home, karantina wilayah hingga pembatasan sosial berskala besar (PSBB) di beberapa kabupaten dan atau kota. Penanganan kasus COVID-19 di Jawa Timur dilakukan dengan serius, terbukti dengan adanya 99 rumah sakit rujukan khusus pasien COVID-19 (PemprovJatim 2020). Hal ini menandakan bahwa upaya kuratif dan rehabilitatif menjadi penting untuk menekan angka kematian akibat COVID-19.

Gerakan mencegah daripada mengobati terhadap pandemi COVID-19 menjadi satusatunya pilihan yang dapat kita lakukan (Zendrato 2020). Gerakan ini dapat kita lakukan dengan memberi perhatian khusus pada upaya promotif preventif. Upaya preventif dilakukan dengan penerapan isolasi mandiri selama 14 hari bagi orang yang melakukan perjalanan dari wilayah transmisi lokal/zona merah, deteksi dini wilayah oleh fasilitas kesehatan, dan lain sebagainya. Selain itu, upaya promotif yang bisa dilakukan adalah dengan melakukan sosialisasi kepada masyarakat umum. Hal ini menjadi penting mengingat penyakit coronavirus disease ini adalah penyakit yang baru dikenal oleh masyarakat dan mengalami perkembangan yang dinamis pada pencegahan maupun cara penularannya. Selain itu, vaksin COVID-19 hingga saat ini masih belum ditemukan di dunia sehingga tidak ada upaya spesifik dapat diberikan agar tidak ada penularan pada manusia (Gennaro et al. 2020).

Pandemi COVID-19 tidak hanya berdampak pada sektor kesehatan saja, namun juga sektor lainnya seperti pendidikan, ekonomi, pariwisata, dan sebagainya (Uddin et al. 2020). Mempertimbangkan kerugian lain dari penerapan stay at home yang kemudian disusul dengan pemberlakuan kebijakan study at home dan work from home, maka pemerintah melakukan revisi pedoman pencegahan COVID-19 di Indonesia. Penggantian ini disebut new normal yang kemudian diganti dengan istilah adaptasi kebiasaan baru (AKB). Pada penerapan AKB, ditekankan bahwa seluruh sektor sudah mulai berangsur aktif kembali namun dengan tetap menerapkan protokol kesehatan yang ada. Misalnya menggunakan masker, melakukan physical distancing, budaya melakukan cuci tangan yang baik dan benar, dan lain sebagainya.

Kebijakan mengenai adaptasi kebiasaan baru yang menerapkan protokol kesehatan oleh pemerintah harus diikuti dengan adanya sosialisasi kepada masyarakat secara berkelanjutan. Hal ini menjadi penting karena diperkuat dengan fakta bahwa di Indonesia penularan COVID-19 merupakan kategori community transmission (WHO 2020). Kategori ini menandakan bahwa peningkatan kasus yang terjadi setiap harinya karena adanya risiko penularan cukup tinggi antara satu orang dengan orang lainnya 
dalam komunitas atau masyarakat. Masyarakat secara keseluruhan harus dijangkau atas informasi mengenai pentingnya protokol kesehatan pada masa adaptasi kebiasaan baru. Kesiapannya harus dipastikan pada seluruh sektor, baik pariwisata, pendidikan, ekonomi, dan sebagainya.

Salah satu kesiapan dalam adaptasi kebiasaan baru dilakukan pada sektor pendidikan yaitu pondok pesantren yang ada di Jawa Timur. Pondok pesantren memiliki perkembangan dari segi jumlah yang cukup banyak, di Jawa Timur terdapat sejumlah 4.850 pondok pesantren (Kemenag 2019). Kabupaten Lumajang merupakan salah satu kabupaten di Jawa Timur yang merupakan zona merah COVID-19. Di Lumajang terdapat jumlah pondok pesantren yang cukup banyak yaitu sejumlah 154 pondok pesantren (Kemenag 2019). Terdapat tren peningkatan kasus terkonfirmasi positif COVID-19 yang ada di wilayah Kabupaten Lumajang.

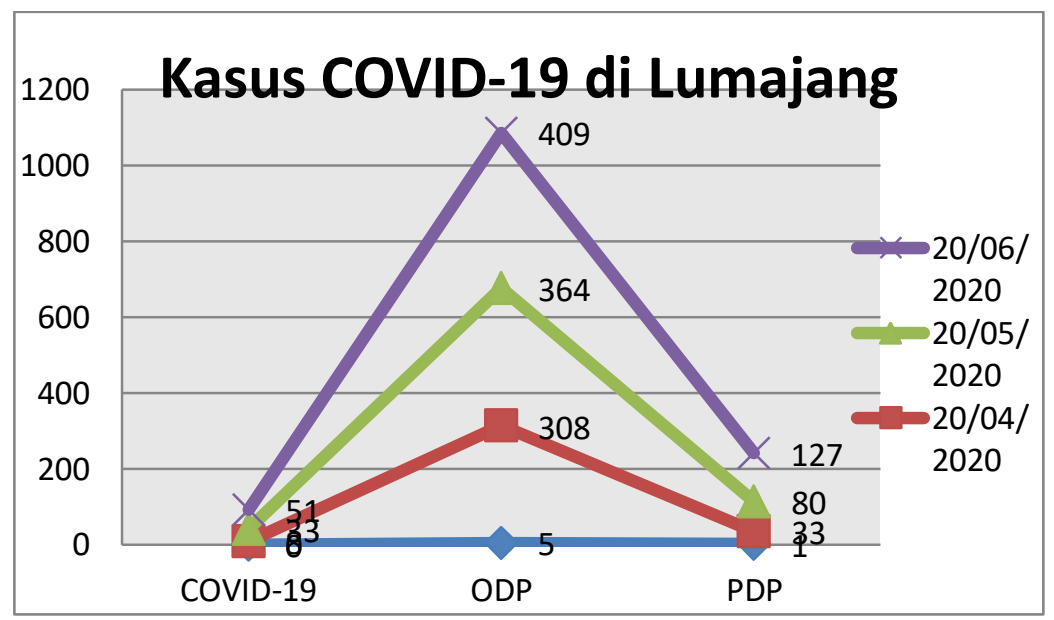

Gambar 1. Kasus COVID-19 di Lumajang Menuju Masa Adaptasi Baru

Menurut gambar 1. Kasus COVID-19 di Lumajang cenderung naik dari bulan Maret hingga Juni 2020. Oleh karena itu, pelaksanaan kebijakan masa adaptasi kebiasaan baru utamanya di Pondok Pesantren menjadi perhatian serius oleh seluruh pihak. Pada bulan Maret 2020 seluruh pondok pesantren yang ada di wilayah Kabupaten Lumajang telah memulangkan seluruh santrinya, hal ini berguna untuk mengurangi penularan kasus COVID-19. Kemudian, pada Juni 2020 seluruh pondok pesantren bersiap untuk mendatangkan kembali santrinya dan memulai kegiatan di pondok pesantren. Banyaknya jumlah pesantren yang akan kembali beraktivitas di masa adaptasi kebiasaan baru (AKB) di Lumajang memiliki potensi munculnya kluster baru dalam pondok pesantren apabila protokol kesehatan tidak dengan serius dilakukan.

Menurut pemaparan diatas, peran sosialisasi dalam pengabdian masyarakat untuk pencegahan penularan COVID-19 di seluruh kecamatan yang ada di Lumajang menjadi penting dilakukan. Di Kabupaten Lumajang terdapat 21 kecamatan dan 14 diantaranya merupakan wilayah zona merah yang menandakan ada kasus positif di kecamatan tersebut. Salah satu kecamatan dengan jumlah kasus terbanyak adalah Kecamatan Sukodono. Hingga 20 Juni 2020, di Sukodono terdapat 6 kasus terkonfirmasi positif dari 51 orang positif COVID-19 di Kabupaten Lumajang (Pemkab Lumajang 2020). 
Hal ini menyebabkan kecamatan Sukodono menjadi kecamatan terbanyak kedua jumlah positif orang terjangkit coronavirus di Lumajang.

Berdasarkan kondisi pandemi COVID-19 di kecamatan Sukodono yang masih mengkhawatirkan menjelang adaptasi kebiasaan baru. Maka kegiatan pengabdian berupa sosialisasi di pondok pesantren yang ada di Kecamatan Sukodono bertujuan untuk meningkatkan pengetahuan santri yang akan beraktivitas di pondok pesantren selama masa pandemi COVID-19 di wilayah kerja Puskesmas Sukodono terkait cara pencegahan penularan COVID-19. Nantinya diharapkan, seluruh santri yang mengikuti kegiatan ini dapat menerapkan protokol kesehatan yang baik demi menjaga kesehatan diri sendiri dan orang lain di sekitarnya.

\section{METODE PENGABDIAN MASYARAKAT}

Kegiatan pengabdian masyarakat yang dilakukan berupa sosialisasi kepada santri di Pondok Pesantren Manarul yang berada di wilayah kerja Puskesmas Sukodono, Lumajang. Kegiatan ini merupakan salah satu bentuk kegiatan pengabdian masyarakat dari volunteer yang dilakukan oleh mahasiswa Fakultas Kesehatan Masyarakat saat masa pandemi COVID-19. Pelaksanaan kegiatan tetap dengan memperhatikan protokol kesehatan dan penggunaan alat pelindung diri (APD) yang sesuai.

Metode lain yang digunakan berupa praktik langsung, yaitu dengan dilakukannya kegiatan praktik 6 langkah mencuci tangan yang baik dan benar menurut WHO oleh seluruh santri. Fokus dari kegiatan ini adalah untuk meningkatkan pengetahuan santri yang diikuti dengan perubahan sikap positif dalam rangka mencegah penularan COVID19 di pondok pesantren. Kegiatan ini diikuti oleh 60 santri yang terdaftar di pondok pesantren Manarul dengan didampingi oleh guru serta pengurus pondok pesantren.

\section{HASIL DAN PEMBAHASAN}

Kegiatan sosialisasi yang dilakukan mendapatkan respon yang positif baik dari guru dan pengurus maupun santri. Hal ini dikarenakan masih belum ada kegiatan sejenis yang dilakukan oleh internal pondok pesantren dalam menyambut kedatangan santri pada masa pandemi COVID-19. Jumlah santri yang mengikuti kegiatan sosialisasi adalah sejumlah 60 orang santri. Kegiatan sosialisasi dibagi menjadi dua hari, jumlah santri yang terlibat di hari pertama sebanyak 35 orang, sementara pada hari kedua yaitu sebanyak 25 orang. Jumlah santri yang mengikuti kegiatan ini sengaja dibatasi untuk memastikan protokol kesehatan yaitu physical distancing tetap berlaku.

Sebelum dilakukan kegiatan sosialisasi terkait pandemi COVID-19, dilakukan pre-test kepada seluruh santri. Kemudian, setelah sosialisasi dilakukan, dilanjutkan dengan pemberian post-test untuk mengetahui ada tidaknya peningkatan pengetahuan pada santri. Pre-test dan post-test dilakukan dengan memberikan pertanyaan tertutup sejumlah 15 soal. Soal yang diberikan terkait dengan cara penularan coronavirus, cara pencegahan, penerapan protokol kesehatan, asal usul COVID-19, dan seputar kondisi COVID-19 di Indonesia. Jawaban yang dipilih akan dibedakan menjadi jawaban benar dan salah.

Pondok Pesantren Manarul dipilih sebagai sasaran kegiatan pengabdian masyarakat ini karena merupakan satu-satunya pondok pesantren yang belum memiliki Pos Kesehatan 
Pesantren (poskestren) di kecamatan Sukodono. Hal ini dikarenakan lembaga pondok pesantren ini baru terbentuk kurang dari lima tahun sehingga secara formal belum ada pembentukan poskestren. Padahal poskestren merupakan salah satu hal yang penting untuk pembangunan kesehatan yang baik di wilayah pondok pesantren. Poskestren merupakan salah satu bentuk pemberdayaan masyarakat yang bersumberdaya dari masyarakat di lingkungan pondok pesantren, dengan menerapkan prinsip dari, oleh dan warga pondok pesantren (Kemenag 2019). Menurut penelitian terdahulu, didapatkan hasil bahwa poskestren memiliki dampak bagi perubahan perilaku santri untuk lebih menerapkan Perilaku Hidup Bersih dan Sehat atau PHBS (Rif'ah 2019). Tidak adanya poskestren akan membuat tidak terintegrasinya data perkembangan kesehatan santri maupun upaya mengurangi masalah kesehatan yang ada, utamanya saat masa pandemi COVID-19.

Kegiatan pengabdian masyarakat yang dilakukan kepada santri dilakukan selama 2 hari. Pada tanggal 3 Juni 2020 diadakan gelombang pertama pukul 13.00-15.30 WIB untuk. Sementara itu, gelombang kedua dilakukan pada 4 Juni 2020 pada pukul 09.00 WIB sampai selesai. Kegiatan yang ada terdiri dari beberapa kegiatan yaitu: pembukaan, perkenalan, pre-test, sosialisasi sesi 1, dan sosialisasi sesi 2. Kemudian dilanjutkan dengan diskusi dan tanya jawab oleh santri kepada pamteri, post-test, praktik cuci tangan dengan 6 langkah menurut WHO.

Berikut adalah perolehan rata-rata yang didapatkan oleh seluruh santri yang mengikuti kegiatan.

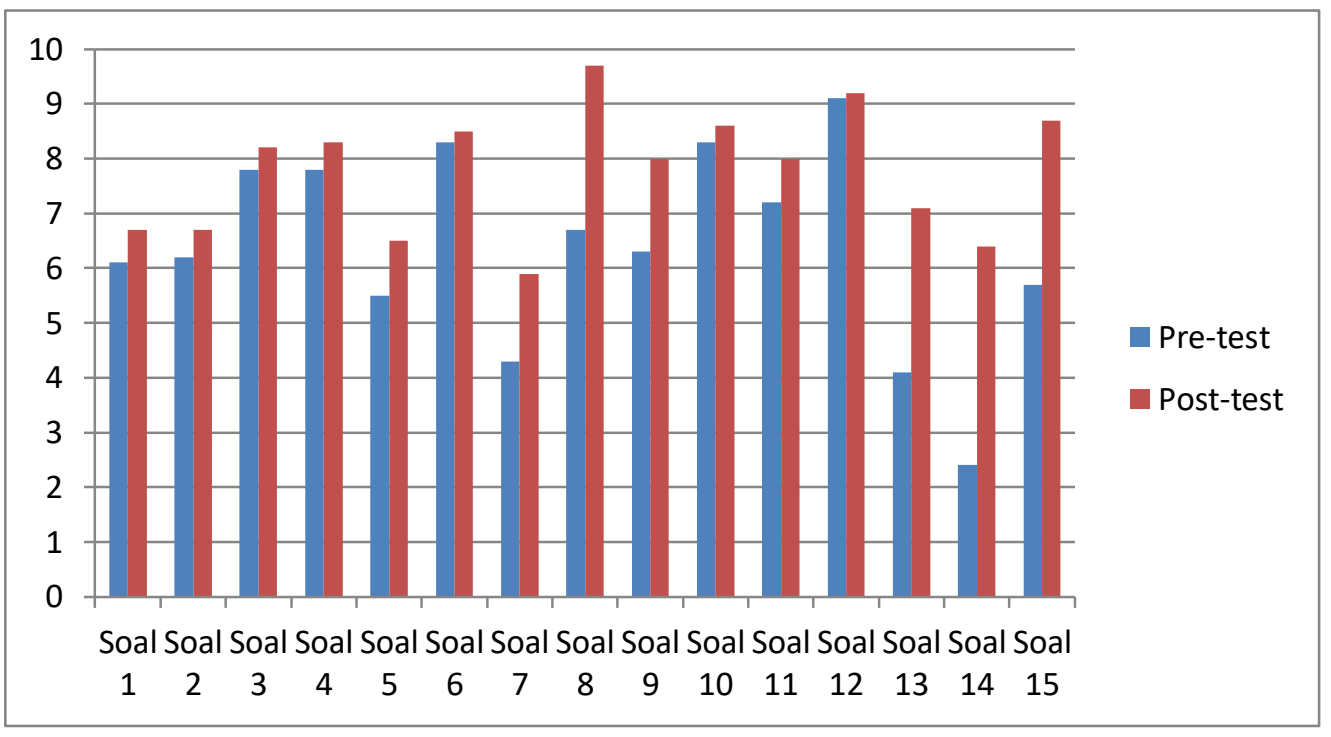

Gambar 2. Rata-rata hasil pre-test dan post-test pada santri

Menurut gambar 2 tentang rata-rata hasil yang diperoleh seluruh santri, dapat dilihat bahwa hasil post-test menunjukkan rata-rata lebih tinggi dibanding pre-test. Rata-rata pretest yang didapatkan oleh santri yaitu 6,38. Namun, setelah mendapatkan sosialisasi dan dilakukan post-test rata-ratanya meningkat menjadi 7,76. Hal ini menandakan adanya peningkatan pengetahuan yang dimiliki oleh santri setelah adanya kegiatan sosialisasi. Hal ini sejalan dengan penelitian lain menyatakan bahwa dibutuhkan upaya untuk memotivasi agar seseorang mau untuk melakukan kebiasaan preventif terhadap 
penyebaran COVID-19 melalui pemaparan data dan kondisi yang ada di sekitarnya (Broucke 2020). Selain itu, menurut penelitian terdahulu pada bidang pengabdian masyarakat juga didapatkan hasil bahwa penyuluhan atau sosialisasi dapat meningkatkan pengetahuan dengue pada ibu, khususnya pada upaya ibu dalam memberantas tempat perindukan jentik nyamuk di Tulungagung, Jawa Timur (Juniastuti et al. 2020).

Sebagai upaya untuk memastikan pengetahuan yang diberikan dapat disalurkan dengan baik, maka selama proses sosialisasi juga dilakukan pembagian leaflet kepada seluruh santri. Leaflet yang disebarkan memuat beberapa informasi yaitu terkait coronavirus, cara pencegahan, gejala klinis, 6 langkah cuci tangan dan protokol kesehatan lainnya. Media leaflet dipilih karena dalam satu kertas dapat memuat banyak informasi yang disajikan secara menarik melalui berbagai gambar. Menurut penelitian terdahulu, didapatkan hasil bahwa pengetahuan kader PHBS mengalami peningkatan setelah adanya intervensi dalam bentuk sosialisasi maupun pelatihan menggunakan leaflet (Saleh and Kunoli 2018). Leaflet yang dibagikan selama sosialisasi berlangsung kemudian dibawa masing-masing oleh santri. Dalam hal ini leaflet bertujuan untuk menjadi media yang bisa dibaca ketika suatu ketika dibutuhkan kembali untuk menggali informasi.

Salah satu materi sosialisasi yang diberikan adalah mengenai cuci tangan menggunakan sabun dan air mengalir sesuai standar WHO. Menurut penelitian terdahulu, terdapat hubungan antara peningkatan pengetahuan dengan tindakan cuci tangan yang baik (Lestari 2019). Setelah diberikan arahan terkait cuci tangan, dilanjutkan dengan praktik cuci tangan untuk menjaga kebersihan dan kesehatan fisik santri selama berada di pondok pesantren. Sarana dan prasarana yang disediakan pihak pondok pesantren untuk kegiatan cuci tangan dirasa sudah memadai. Hal ini dibuktikan dengan adanya kran air di pintu masuk dan beberapa titik tempat umum yang tersebar di seluruh pondok pesantren dan sudah dilengkapi dengan sabun cuci tangan. Namun faktanya meskipun sarana sudah mendukung, santri masih belum menerapkan budaya mencuci tangan. Faktor yang menjadi penyebabnya antara lain santri belum mengetahui cara mencuci tangan yang baik dan benar. Ketidaktahuan ini membuat budaya cuci tangan di kalangan santri menjadi asing. Mencuci tangan yang baik menggunakan sabun dan air yang mengalir adalah bagian dan higiene personal dan saat ini menjadi salah satu cara untuk mencegah penularan coronavirus.

\section{PENUTUP}

\section{Simpulan}

Menurut hasil dari pengabdian masyarakat yang telah dilakukan, dapat disimpulkan bahwa kegiatan sosialisasi sebagai upaya pencegahan penularan COVID-19 berdampak baik pada peningkatan pengetahuan santri dalam upaya pencegahan penularan coronavirus. Kegiatan lainnya yang berpengaruh yaitu praktik cuci tangan dengan teknik 6 langkah menggunakan sabun dan air yang mengalir kepada para santri.

\section{Saran}

Saran yang diberikan yaitu perlu dilakukan tindak lanjut berupa monitoring dan evaluasi penerapan protokol kesehatan di pondok pesantren selama masa pandemi COVID-19. 
Kegiatan tersebut bisa dilakukan pihak pondok pesantren dan pihak lain terkait misalnya Puskesmasuntuk memastikan bahwa tindakan seluruh santri tetap baik dalam menerapkan protokol kesehatan. Protokol kesehatan yang dimaksudkan adalah seperti tertib dalam penggunaaan masker, mencuci tangan sesering mungkin, dan physical distancing.

\section{DAFTAR PUSTAKA}

Broucke, Stephan Van den. 2020. "Why Health Promotion Matters to the COVID-19 Pandemic, and Vice Versa." Health Promot Int. 35 (2): 181-86. https://doi.org/10.1093/hearo/daaa042.

Gennaro, Francesco Di, Damiano Pizzol, Claudia Marotta, Mario Antunes, Vincezo Racabulto, Nicola Veronese, and Lee Smith. 2020. "Coronavirus Disease (COVID-19) Current Status and Future Perspective: A Narative Review." Environment Research and Public Health 17: 1-11. https://doi.org/10.3390/iejprh17082690.

Juniastuti, Rossyanti Lynda, Wahyunitiasi Mamik R, Achmad Ardianto, Rebekah J Setiabudi, Suhintam Usarawati, Setyowati, and Putri S Wulandari. 2020. "Penyuluhan dan Pelatihan Dengue Pada Ibu Serta Deteksi Dini Infeksi Dengue Pada Pasien Dengan Suspek Infeksi Dengue di Tulungagung, Jawa Timur.” Jurnal Layanan Masyarakat 4 (1): 230-36.

Kemenag. 2019. "Nomor Statistik Pondok Pesantren." Jakarta: Kementerian Agama Republik Indonesia.

Kemenkes. 2020. "Perkembangan Covid-19 Indonesia." 2020. http://pusatkrisis.kemkes.go.id/covid-19-id/\%0A.

Lestari, Audira Octa Anggraini. 2019. "Hubungan Pengetahuan Dan Sikap Terhadap Perilaku Cuci Tangan Pada Masyarakat Kelurahan Pegirian." Jurnal Promkes: The Indonesia Journal of Health Promotuon and Health Education 7 (1): 1-11.

Pemkab Lumajang. 2020. "Peta Sebaran COVID-19 Kabupaten Lumajang." 2020. https://info.covid.lumajang.go.id/main/peta_sebaran.

PemprovJatim. 2020. "JATIM TANGGAP COVID-19." 2020. http://infocovid19.jatimrov.go.id/.

Rif'ah, Erwin Nur. 2019. "Pemberdayaan Pusat Kesehatan Pesantren ( POSKESTREN ) Untuk Meningkatkan Perilaku Hidup." Warta Pengabdian 13 (3): 96-105. https://doi.org/10.19184/wrtp.v13i3.11862.

Saleh, Azizah, and Firdaus J Kunoli. 2018. "Pengaruh Penyuluhan Dan Pelatihan Melalui Media Leaflet Terhadap Pengetahuan Kader PHBS Di Kecamatan Ratolindo Kabupaten Tojo Una-Una." Promotif: Jurnal Kesehatan Masyarakat 8 (2): 159-63. 
Uddin, Mohammed, Farah Mustafa, Tahir A Rizvi, Tom Loney, Hanan Al Suwaidi, Ahmed H Hassan Al-marzouqi, Afaf Kamal Eldin, et al. 2020. "SARS-CoV2/COVID-19: Viral Genomics, Epidemiology, Vaccines and Therapeutic Interventions." Viruses 2020 12: 1-18. https://doi.org/doi:10.3390/v12050526.

WHO. 2020. “WHO Coronavirus Disease (COVID-19) Dashboard.” 2020. https://covid19.who.int/table.

Zendrato, Walsyukurniat. 2020. “GERAKAN MENCEGAH DARIPADA MENGOBATI TERHADAP PANDEMI COVID-19." Jurnal Education and Development 8 (2): 242-48. 